Article

\title{
Paddlewheelite, a New Uranyl Carbonate from the Jáchymov District, Bohemia, Czech Republic
}

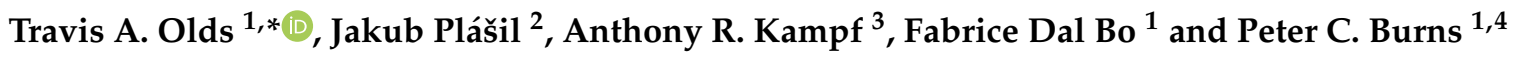 \\ 1 Department of Civil and Environmental Engineering and Earth Sciences, University of Notre Dame, \\ Notre Dame, IN 46556, USA; fabrice.dalbo@gmail.com (F.D.B); pburns@nd.edu (P.C.B.) \\ 2 Institute of Physics, Academy of Sciences of the Czech Republic, v.v.i., Na Slovance 1999/2, 18221 Prague 8, \\ Czech Republic; jakub.horrak@gmail.com \\ 3 Mineral Sciences Department, Natural History Museum of Los Angeles County, 900 Exposition Boulevard, \\ Los Angeles, CA 90007, USA; akampf@nhm.org \\ 4 Department of Chemistry and Biochemistry, University of Notre Dame, Notre Dame, IN 46556, USA \\ * Correspondence: toldxls@gmail.com
}

Received: 10 October 2018; Accepted: 5 November 2018; Published: 7 November 2018

\begin{abstract}
Paddlewheelite, $\mathrm{MgCa}_{5} \mathrm{Cu}_{2}\left[\left(\mathrm{UO}_{2}\right)\left(\mathrm{CO}_{3}\right)_{3}\right]_{4} \cdot 33 \mathrm{H}_{2} \mathrm{O}$, is a new uranyl carbonate mineral found underground in the Svornost mine, Jáchymov District, Bohemia, Czech Republic, where it occurs as a secondary oxidation product of uraninite. The conditions leading to its crystallization are complex, likely requiring concomitant dissolution of uraninite, calcite, dolomite, chalcopyrite, and andersonite. Paddlewheelite is named after its distinctive structure, which consists of paddle-wheel clusters of uranyl tricarbonate units bound by square pyramidal copper "axles" and a cubic calcium cation "gearbox." Paddle wheels share edges with calcium polyhedra to form open sheets that are held together solely by hydrogen bonding interactions. The new mineral is monoclinic, $P c$, $a=22.052(4), b=17.118(3), c=19.354(3) \AA, \beta=90.474(2)^{\circ}, V=7306(2) \AA^{3}$ and $Z=4$. Paddlewheelite is the second-most structurally complex uranyl carbonate mineral known after ewingite and its structure may provide insights into the insufficiently described mineral voglite, as well as $\mathrm{Cu}-\mathrm{U}-\mathrm{CO}_{3}$ equilibrium in general.
\end{abstract}

Keywords: new mineral; uranyl carbonate; crystal structure; complexity; paddle

\section{Introduction}

Recent uranyl carbonate mineral discoveries have uncovered remarkably complex topological arrangements that formed under restrictive conditions of $\mathrm{Ca}-\mathrm{U}-\mathrm{CO}_{3}$ equilibria [1-3]. In part, these new minerals lend their complexity to hydrated calcium polyhedra found in their structures, which can share numerous geometrical elements with uranyl tricarbonate units (UTC), $\left(\mathrm{UO}_{2}\right)\left(\mathrm{CO}_{3}\right)_{3}{ }^{4-}$, to form multidimensional structures. For example, UTC units in andersonite and liebigite form finite cluster topologies of "zero" dimensionality, as defined by the structural hierarchy for uranyl minerals [4,5], where one or more uranyl polyhedra link to oxyanions and share no other connections to high valence cations. Recently described minerals, such as ewingite and the description of paddlewheelite given here, reveal that the finite UTC clusters can assemble as large hollow cages and complex 3D paddle arrangements. While other Ca-UTC minerals such as fontanite and roubaltite contain structural units built from infinite sheets (2D), no uranyl carbonate minerals known today contain isolated polyhedra (0D), chains (1D), or framework (3D) topologies.

It is well understood that Ca-UTC complexes are some of the most stable aqueous uranyl species in groundwater [6,7], and that uranyl carbonate minerals are consequently pervasive alteration products found in oxidizing areas of abandoned uranium mines and their tailings [8], and may be found on 
the surface of used nuclear fuel exposed to groundwater. Uranyl carbonate minerals can record and be used to diagnose groundwater conditions at the moment of crystallization, allowing for more accurate safety assessments of $U$ contaminated water transport and longer-term radionuclide release models for Ca-U-C systems. Here we describe the crystal-chemical and spectroscopic properties of the new $\mathrm{Ca}-\mathrm{Mg}-\mathrm{Cu}$ uranyl carbonate mineral paddlewheelite, whose structure contains several first known instances for uranyl minerals, including isolated square pyramidal copper polyhedra and calcium cations in cubic coordination. These two unique cation polyhedra bind to UTC units, forming an extraordinary paddlewheel motif arranged into an open-sheet topology that may provide several clues to understanding the structure and formation of the poorly described mineral voglite, $\mathrm{Ca}_{2} \mathrm{Cu}\left(\mathrm{UO}_{2}\right)\left(\mathrm{CO}_{3}\right)_{4} \cdot 6 \mathrm{H}_{2} \mathrm{O}[9]$.

The name paddlewheelite was chosen to reflect the unique structure of the mineral that resembles the paddlewheel of a steamboat. Four uranyl tricarbonate paddles are bound by two square pyramidal $\mathrm{CuO}_{5}$ "axles" and a $\mathrm{CaO}_{8}$ "gearbox" in cubic coordination. The new mineral and its name were approved by the Commission on New Minerals, Nomenclature and Classification of the International Mineralogical Association (IMA2017-098). The holotype specimen is deposited in the Natural History Museum of Los Angeles County, under catalogue number 66696.

\section{Occurrence}

Crystals of paddlewheelite were collected underground from a bifurcation of the Prokop vein on the 5th level of the Svornost mine, Jáchymov District, Bohemia, Czech Republic. The Svornost mine (Einigkeit in German, Concord in English) is named for one of the six major ore clusters in the Jáchymov ore district. "Five-element" (Ni-Co-As-Ag-Bi, +/ - U) mineralization was deposited there during episodic fracturing and space filling by metal-rich hydrothermal solutions. Further details regarding the geology and hydrothermal history of the Jáchymov district are given elsewhere [10-13]. Today, the Svornost mine workings are abandoned for mining but are maintained by a small group of workers employed by the radon spa company, Léčebné lázně Jáchymov (Therapeutic spa Jáchymov). Post-mining alteration has produced many chemically and structurally complex secondary uranyl minerals there, including paddlewheelite, which is one of the rarest U-minerals found there to date.

The excavated section of the Prokop vein where paddlewheelite occurs is rich in carbonates, sulfides, and uraninite. The Prokop vein generally strikes N-S and is considered a "midnight" vein according to the local terminology given by miners. The so-called midnight veins are among the richest U-bearing veins in the district, ranging in size from centimeters up to several meters in thickness with complex morphology. In general, pectinate-structured quartz, consisting of tightly packed prismatic crystals with smoky terminations form the Prokop vein wall, followed by a subsequent inner layer of sulfides and uraninite, with final filling by dolomite and calcite. Paddlewheelite was found occurring with calcite, dolomite, and chalcopyrite in an area of vein near the tunnel floor that was rich in andersonite. In addition, a single relatively large crystal $(\sim 400 \mu \mathrm{m})$ with complex growth features was located within a fracture between chalcopyrite and dolomite crystals and was used for the entire new mineral description given here (Figure 1). Other closely associated minerals include matte grayish-black coffinitized uraninite, quartz, hematite, goethite (var. "sammetblende"), and calcite. Paddlewheelite was formed under chemically complex conditions with simultaneous or concomitant dissolution of its associated minerals, uraninite, dolomite, calcite, chalcopyrite, and andersonite. 


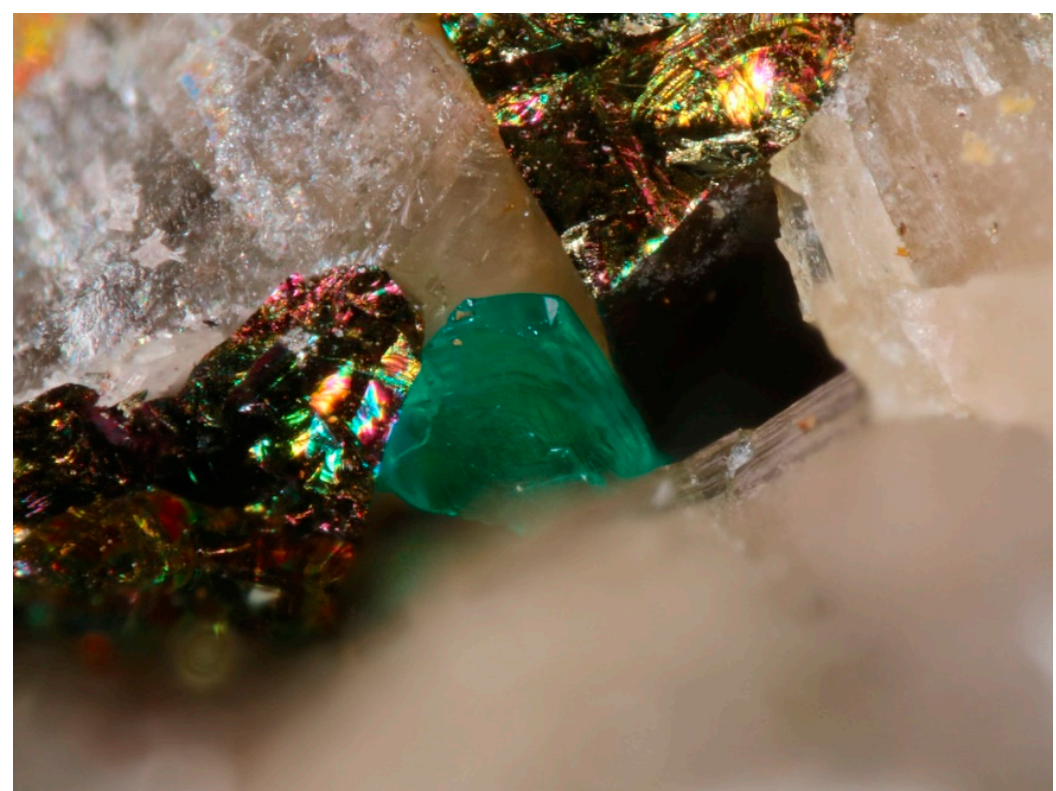

Figure 1. Green tabular crystal of paddlewheelite in a cavity of dolomite and chalcopyrite. Horizontal field of view is $1.8 \mathrm{~mm}$.

\section{Appearance and Physical Properties}

Paddlewheelite occurs as cleavages coating and wedged between the interstices of calcite, dolomite, and chalcopyrite, and also as tabular crystals flattened on $\{100\}$ (Figures 1 and 2). Crystals are blue green in color with shading close to Pantone 334c, are transparent with sub-adamantine luster and very pale blue green streak. Paddlewheelite exhibits no fluorescence under long- or short-wave UV illumination, and twinning was not apparent. Based on scratch tests, the hardness is about 2, with brittle tenacity and at least one perfect cleavage on $\{100\}$. Due to limited availability of crystals the density was not measured directly but it is calculated to be $2.497 \mathrm{~g} / \mathrm{cm}^{3}$ based on the ideal formula, and $2.435 \mathrm{~g} / \mathrm{cm}^{3}$ based on the empirical formula. Crystals of paddlewheelite are immediately soluble with effervescence in dilute $\mathrm{HCl}$ at room temperature.

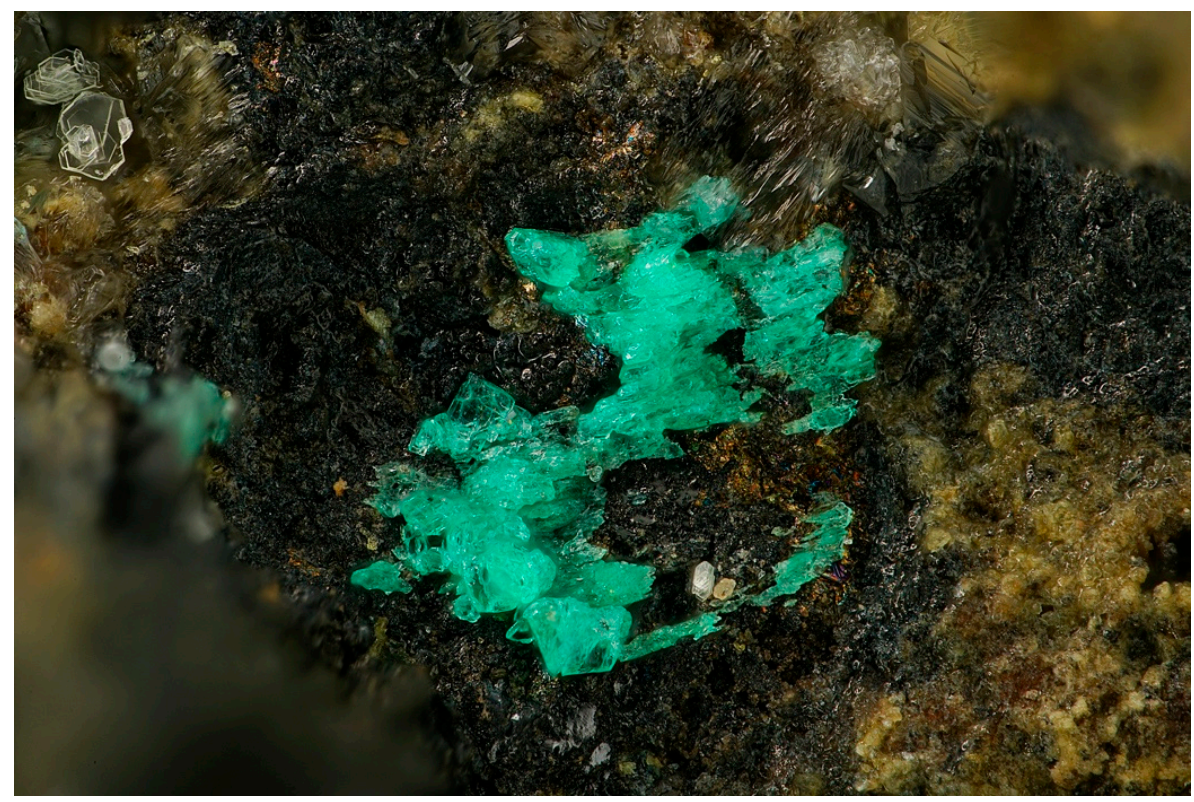

Figure 2. Thin green platelettes of paddlewheelite coating chalcopyrite and andersonite. Horizontal field of view is $2 \mathrm{~mm}$. Photo by Stephan Wolfsried. 
Paddlewheelite is optically biaxial (+), with $\mathrm{nx}=1.520(2)$, ny $=1.527(2), \mathrm{nz}=1.540(2)$, (measured in white light). The $2 V$ is $72(1)^{\circ}$, measured by conoscopic observation on a spindle stage; the calculated $2 V$ is $73.1^{\circ}$. Dispersion is slight, $r<v$. The mineral is pleochroic with $X$ and $Y$ blue green, and $Z$ pale yellow; $X \approx Y>>Z$. The optical orientation is $Z / / \mathbf{b}, X=\mathbf{a}, Y=\mathbf{c}$. The Gladstone-Dale compatibility, $1-\left(\mathrm{K}_{\mathrm{p}} / \mathrm{K}_{\mathrm{c}}\right)$, is 0.037 (excellent) for the ideal formula, and -0.056 (good) using the empirical formula—where $k\left(\mathrm{UO}_{3}\right)=0.134$ provided by Larsen [14] yields a better fit than $k\left(\mathrm{UO}_{3}\right)=0.118$ given by Mandarino [15]. Parameters for the remaining components were taken from Mandarino [15].

\section{Infrared Spectroscopy}

Attenuated total reflectance (ATR) Fourier transform infrared (FTIR) spectra were obtained using a SENSIR Technologies IlluminatIR (SensIR Technologies, Danbury, CT, USA) with a liquid $\mathrm{N}_{2}$ cooled MCT detector mounted to an Olympus BX51 microscope (Olympus, Tokyo, Japan). An ATR objective (ZnSe/diamond composite) was pressed into fragments of paddlewheelite crystals and the spectrum was measured from 4000 to $650 \mathrm{~cm}^{-1}$ (Figure 3). The band assignments given here are based on those outlined by Čejka [16]. A broad, multicomponent band spanning from $\sim 3500$ to $\sim 2800 \mathrm{~cm}^{-1}$ is related to $\vee \mathrm{O}-\mathrm{H}$ stretching vibrations of water molecules (Figure 4a). The series of fitted bands in this region lie at $3515,3377,3200,3026$, and $2850 \mathrm{~cm}^{-1}$. Approximate $\mathrm{O}-\mathrm{H} \cdots \mathrm{O}$ hydrogen bond-lengths calculated from the observed frequencies lie within the range $\sim 2.9$ to $2.6 \AA$ using the correlation function given by Libowitzky [17]. A weak band found at $1632 \mathrm{~cm}^{-1}$ is assigned to the $v_{2}(\delta)$-bending vibration of molecular water.

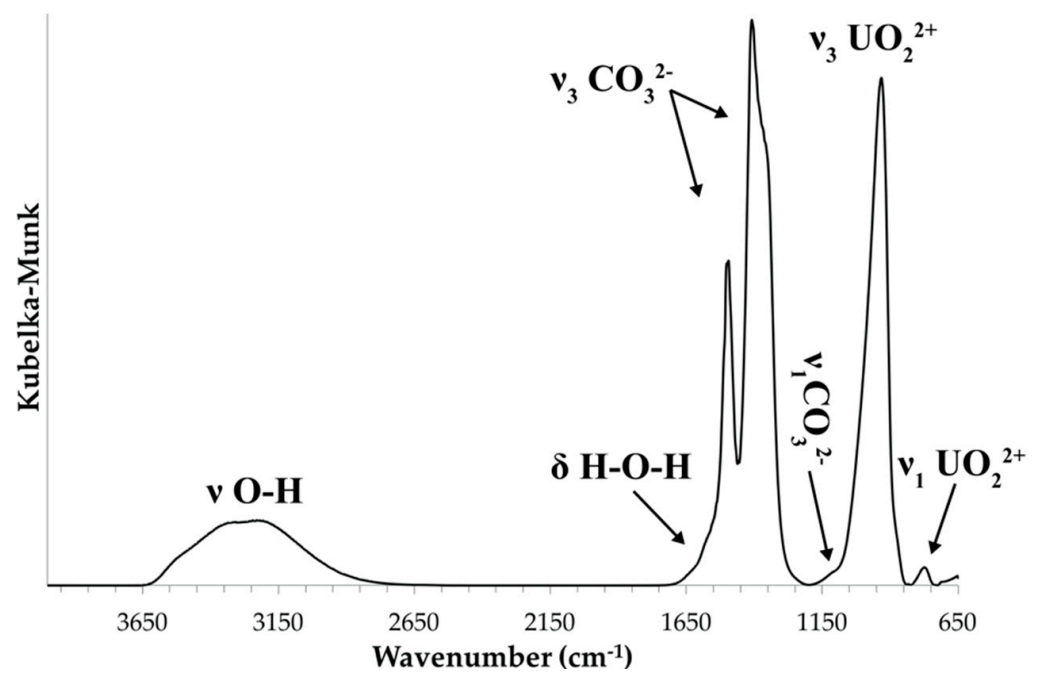

Figure 3. Infrared (ATR) spectrum of paddlewheelite from 4000 to $650 \mathrm{~cm}^{-1}$.
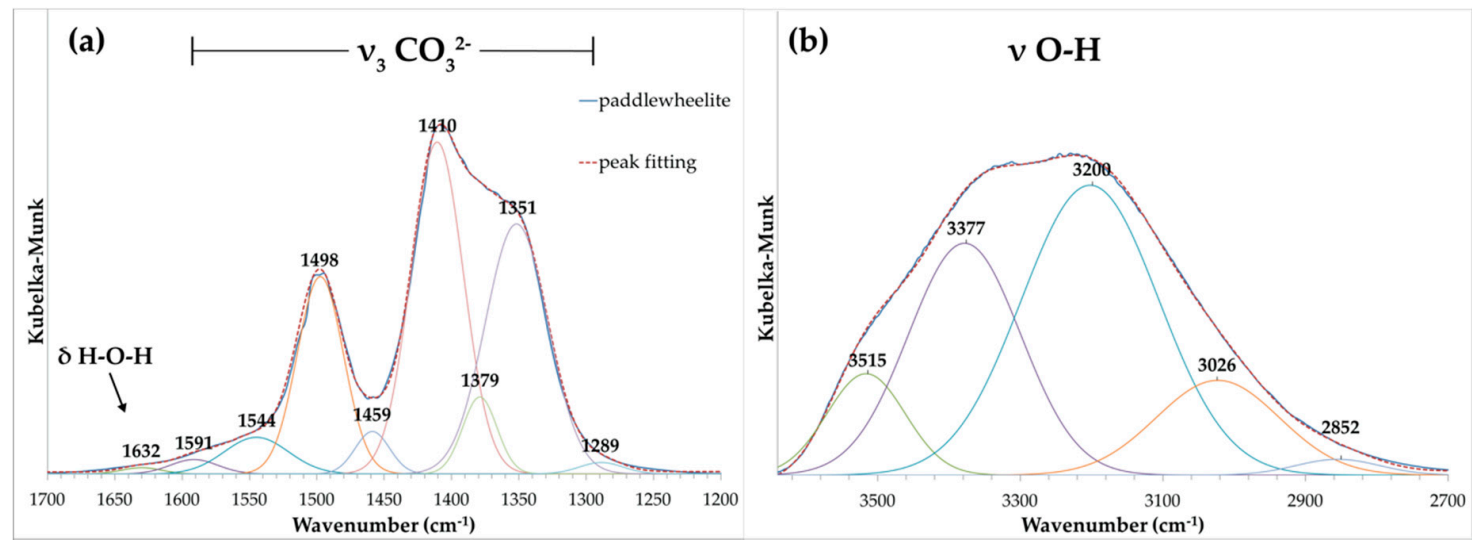

Figure 4. Fitted infrared spectrum of paddlewheelite in the (a) $\mathrm{CO}_{3}{ }^{2-}$ and (b) $\mathrm{O}-\mathrm{H}$ stretching regions. 
Significant splitting of the $\mathrm{v}_{3} \mathrm{CO}_{3}{ }^{2-}$ antisymmetric stretching vibration occurs at $1591(\mathrm{w}), 1544(\mathrm{w})$, 1498 (s), 1459 (w), 1410 (s), 1379 (w), 1351 (s), and 1289 (w) cm ${ }^{-1}$ (Figure 4b). Their splitting confirms the presence of multiple independent $\mathrm{CO}_{3}{ }^{2-}$ groups in the structure of paddlewheelite. The symmetric stretching $v_{1} \mathrm{CO}_{3}{ }^{2-}$ vibration, though IR-forbidden, occurs as a weak band at $1115 \mathrm{~cm}^{-1}$ due to symmetry lowering. A very strong band attributed to the antisymmetric stretching vibration $v_{3} \mathrm{UO}_{2}{ }^{2+}$ occurs at $931.5 \mathrm{~cm}^{-1}$. Bartlett and Cooney [18] developed an empirical relationship to derive the approximate uranyl $\left(\mathrm{U}-\mathrm{O}_{\mathrm{yl}}\right)$ bond lengths from the band position assigned to the $\mathrm{v}_{3} \mathrm{UO}_{2}{ }^{2+}$ symmetric stretching vibration, giving $1.76 \AA\left(931.5 \mathrm{~cm}^{-1}\right)$; in very good agreement with average $\mathrm{U}-\mathrm{O}_{\mathrm{yl}}$ bond length from the structure, $1.76 \AA$. The $v_{2}(\delta) \mathrm{CO}_{3}{ }^{2-}$ bending mode, if present, is weak and obscured by the intense $v_{3} \mathrm{UO}_{2}{ }^{2+}$ stretch, and the weak band at $771 \mathrm{~cm}^{-1}$ may be attributed to coincidence of either $v_{1} \mathrm{UO}_{2}{ }^{2+}$ or the $v_{4}(\delta) \mathrm{CO}_{3}{ }^{2-}$ in-plane bending vibration.

\section{Chemical Data}

Chemical analyses (6) were made using a Cameca SX50 electron microprobe (Cameca, Gennevilliers, France) operated at $15 \mathrm{kV}, 30 \mathrm{nA}$, with a $5 \mu \mathrm{m}$ beam diameter, and the data are given below in Table 1. Matrix effects were accounted for using the "PAP" correction routine by Pouchou and Pichoir [19]. Paddlewheelite contains major $\mathrm{Mg}, \mathrm{Ca}, \mathrm{Cu}$, and $\mathrm{U}$, with minor $\mathrm{Si}$ and Fe. No other elements were detected, and the presence of $\mathrm{H}_{2} \mathrm{O}$ and $\mathrm{CO}_{3}{ }^{2-}$ was confirmed by infrared spectroscopy. Due to the limited amount of material available the $\mathrm{H}_{2} \mathrm{O}$ content could not be measured, but is instead calculated based on the structure, with $77 \mathrm{O} a p f u$. In the absence of a direct determination of $\mathrm{CO}_{2}$, the empirical formula is calculated for $4 \mathrm{U}$ with $12 \mathrm{CO}_{3} p f u$ as obtained from the structure determination. Crystals of paddlewheelite were heavily dehydrated and fractured in the vacuum chamber, leading to abnormally high $U$ totals and low count rates that required measurements at relatively high current. We encountered additional difficulties during the analysis of $\mathrm{Cu}$, which exhibited strong depletion over the analysis time because of the high beam current used. Such loss is also observed in metatorbernite [20], and when using small beam sizes, where typical zero-time functions to fit loss are insufficient for accurate composition calculations [21].

Table 1. Analytical data (wt. \%) for paddlewheelite, average of 6 analyses.

\begin{tabular}{cccccc}
\hline Constituent & Mean & Range & Std. Dev. & Normalized & Probe Standard \\
\hline $\mathrm{CaO}$ & 12.47 & $11.71-13.375$ & 0.57 & 10.74 & anorthite \\
$\mathrm{CuO}$ & 2.65 & $1.64-3.26$ & 0.56 & 2.28 & Cu metal \\
$\mathrm{FeO}$ & 0.01 & $0-0.04$ & 0.01 & 0.01 & Olivine \\
$\mathrm{MgO}$ & 1.7 & $1.16-1.93$ & 0.28 & 1.47 & Olivine \\
$\mathrm{SiO}$ & 0.42 & $0-0.93$ & 0.36 & 0.36 & Olivine \\
$\mathrm{UO}_{3}$ & 49.38 & $48.22-50.69$ & 1.13 & 42.97 & $\mathrm{UO}_{2}$ (syn.) \\
$\mathrm{CO}_{2}$ & 22.8 & - & - & 19.84 & \\
$\mathrm{H}_{2} \mathrm{O}^{*}$ & 25.66 & - & - & 22.33 & \\
Total & 115.09 & & & 100.00 & \\
\hline
\end{tabular}

* Based on structure.

The empirical formula, calculated on the basis of $77 \mathrm{O}$ and $4 \mathrm{U}$ apfu is $\mathrm{Mg}_{0.98} \mathrm{Ca}_{5.16} \mathrm{Cu}_{0.77} \mathrm{Si}_{0.16} \mathrm{U}_{4} \mathrm{O}_{77}$ $\mathrm{C}_{12} \mathrm{H}_{66}$, or $\mathrm{Mg}_{0.98} \mathrm{Ca}_{5.16} \mathrm{Cu}_{0.77} \mathrm{Si}_{0.16}\left(\mathrm{UO}_{2}\right)_{4}\left(\mathrm{CO}_{3}\right)_{12}\left(\mathrm{H}_{2} \mathrm{O}\right)_{33}$. The ideal formula is $\mathrm{MgCa}_{5} \mathrm{Cu}_{2}\left[\left(\mathrm{UO}_{2}\right)\left(\mathrm{CO}_{3}\right)_{3}\right]_{4}$. $33 \mathrm{H}_{2} \mathrm{O}$, which requires $\mathrm{UO}_{3} 41.65, \mathrm{CaO} 10.21, \mathrm{CuO} 5.80, \mathrm{MgO} 1.47, \mathrm{CO}_{2} 19.23, \mathrm{H}_{2} \mathrm{O} 21.64$, for a total 100 wt. \%.

Due to the poor analytical result for $\mathrm{Cu}$, we have collected additional chemical data for paddlewheelite using Laser Ablation Inductively Coupled Plasma Mass Spectrometry (LA-ICP-MS). A small crystal fragment of paddlewheelite was embedded in epoxy and polished. The ion signals for ${ }^{235} \mathrm{U},{ }^{63} \mathrm{Cu},{ }^{43} \mathrm{Ca},{ }^{57} \mathrm{Fe}$, and ${ }^{26} \mathrm{Mg}$ were measured using an Element 2 sector field high resolution inductively coupled plasma mass spectrometer (Thermo Fisher Scientific, Waltham, MA, USA) in low mass resolution mode coupled with a UP-213 (New Wave Research, Martinsried, Germany) Nd:YAG 
deep UV (213 nm) laser ablation system. Prior to lasering of the crystal, the Element 2 was tuned using a standard solution containing $1 \mathrm{ng} / \mathrm{g}$ each of $\mathrm{Li}$, $\mathrm{In}$, and $\mathrm{U}$ to obtain maximum ion sensitivity. Background ion signals were acquired for 60 seconds with the laser on and shuttered, followed by $60 \mathrm{~s}$ of data acquisition. Three spot analyses were performed using an $8 \mu \mathrm{m}$ spot size, repetition rate of 5 $\mathrm{Hz}, 100 \%$ power out, which corresponded to a fluence of $\sim 8.4 \mathrm{~J}^{*} \mathrm{~cm}^{-2}$. The ion signals (cps- counts per second) obtained for $\mathrm{U}, \mathrm{Cu}, \mathrm{Ca}$, and $\mathrm{Mg}$ are reported as a ratio relative to that recorded for $\mathrm{U}$, as absolute abundances could not be determined due to a lack of an appropriate matrix matched external standard (no other $\mathrm{Mg}-\mathrm{Ca}-\mathrm{Cu}-\mathrm{U}$ carbonates are known). As a result, we are unable to apply corrections to the variable ablation and ionization efficiency of each element causing lower than expected totals. For the three spot analyses based on $4 \mathrm{U}$ apfu, the average empirical cation formula is $\mathrm{Mg}_{0.40} \mathrm{Ca}_{3.20} \mathrm{Cu}_{1.26} \mathrm{U}_{4.00}$. However, the data provide a more accurate indication of the chemical proportions for $\mathrm{U}: \mathrm{Cu}$.

\section{Crystallography}

\subsection{Powder X-ray Diffraction}

Powder diffraction data were recorded using a Rigaku R-Axis Rapid II curved imaging plate microdiffractometer (Rigaku, Tokyo, Japan) with monochromated MoK $\alpha$ radiation. A Gandolfi-like motion on the $\phi$ and $\omega$ axes was used to randomize diffraction from the sample. The observed $d$-values and intensities were derived by profile fitting using JADE 2010 software (Materials Data, Inc., Livermore, CA, USA). These data are given in Table 2. Unit cell parameters refined from the powder data using JADE 2010 (Materials Data, Inc., Livermore, CA, USA) with whole pattern fitting are $a=$ 22.061(4) $\AA, b=17.128(3) \AA, c=19.368(3) \AA, \beta=90.476(2)^{\circ}, V=7318(2) \AA^{3}$. 
Table 2. Powder X-ray data for paddlewheelite ( $d$ values in $\AA$ ). All calculated intensities have been multiplied by 0.36 so that the sum of the intensities of the three calculated lines contributing to the strongest observed line is 100

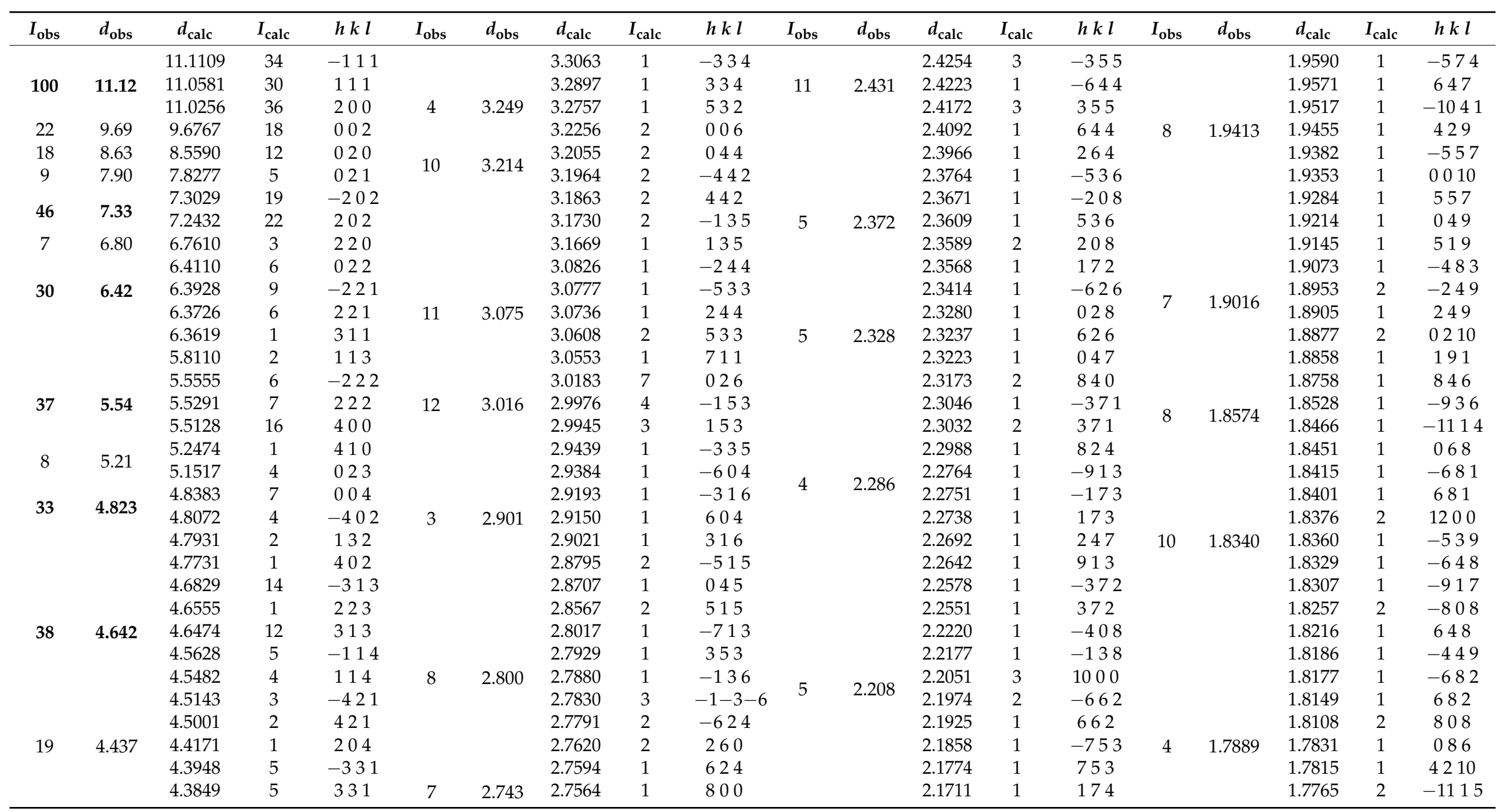


Table 2. Cont

\begin{tabular}{|c|c|c|c|c|c|c|c|c|c|c|c|c|c|c|c|c|c|c|c|}
\hline$I_{\text {obs }}$ & $d_{\text {obs }}$ & $d_{\text {calc }}$ & $I_{\text {calc }}$ & $h k l$ & $I_{\text {obs }}$ & $d_{\text {obs }}$ & $d_{\text {calc }}$ & $I_{\text {calc }}$ & $h k l$ & $I_{\text {obs }}$ & $d_{\text {obs }}$ & $d_{\text {calc }}$ & $I_{\text {calc }}$ & $h k l$ & $I_{\text {obs }}$ & $d_{\text {obs }}$ & $d_{\text {calc }}$ & $I_{\text {calc }}$ & $h k l$ \\
\hline & & 4.2119 & 8 & 024 & & & 2.7365 & 5 & 062 & & & 2.1601 & 1 & 537 & & & 1.7740 & 1 & 1026 \\
\hline \multirow[t]{6}{*}{34} & 4.215 & 4.1913 & 2 & -422 & & & 2.7335 & 1 & 261 & & & 2.1421 & 1 & -157 & & & 1.7716 & 1 & -393 \\
\hline & & 4.1775 & 9 & -511 & & & 2.7060 & 1 & 117 & & & 2.1395 & 1 & 157 & & & 1.7704 & 1 & -359 \\
\hline & & 4.1687 & 1 & 422 & & & 2.6836 & 2 & -642 & & & 2.1348 & 1 & 447 & & & 1.7667 & 1 & 955 \\
\hline & & 4.1634 & 7 & 511 & 8 & 2.686 & 2.6802 & 1 & -551 & 9 & 2.134 & 2.1313 & 1 & 627 & & & 1.7640 & 3 & 194 \\
\hline & & 4.1068 & 1 & -141 & & & 2.6765 & 1 & 551 & & & 2.1268 & 2 & 081 & & & 1.7464 & 1 & 468 \\
\hline & & 4.0938 & 1 & -332 & & & 2.6747 & 2 & 642 & & & 2.1248 & 1 & 571 & 4 & 1.7409 & 1.7392 & 2 & 2410 \\
\hline \multirow{4}{*}{11} & & 4.0779 & 2 & 332 & & & 2.6568 & 2 & -802 & & & 2.1159 & 1 & -646 & & & 1.7241 & 1 & -1151 \\
\hline & 4.027 & 3.9895 & 7 & 240 & & & 2.6452 & 1 & 802 & & & 2.1060 & 2 & 048 & & & 1.7221 & 1 & -394 \\
\hline & & 3.9475 & 3 & -314 & & & 2.6389 & 1 & 426 & & & 2.1037 & 1 & -736 & 5 & 1.7164 & 1.7190 & 1 & -1062 \\
\hline & & 3.9252 & 2 & 224 & & & 2.6294 & 1 & -336 & 11 & 2.106 & 2.1001 & 2 & -266 & & & 1.7183 & 1 & -6010 \\
\hline \multirow{7}{*}{25} & & 3.9192 & 2 & 314 & 7 & 2.622 & 2.6237 & 2 & 820 & & & 2.0958 & 2 & 266 & & & 1.7118 & 1 & 0100 \\
\hline & 3.939 & 3.9138 & 11 & 042 & & & 2.6168 & 1 & 336 & & & 2.0886 & 3 & -281 & & & 1.7046 & 1 & -1135 \\
\hline & & 3.9097 & 2 & -241 & & & 2.6081 & 1 & 354 & & & 2.0856 & 1 & 029 & & & 1.7024 & 1 & -195 \\
\hline & & 3.9051 & 3 & 241 & & & 2.6027 & 1 & -821 & & & 2.0535 & 1 & -319 & & & 1.6949 & 1 & -577 \\
\hline & & 3.7764 & 1 & -423 & & & 2.6002 & 1 & -535 & & & 2.0522 & 1 & -229 & 7 & 1.6930 & 1.6902 & 1 & 880 \\
\hline & & 3.7262 & 6 & -115 & & & 2.5833 & 1 & 535 & & & 2.0462 & 1 & 229 & & & 1.6883 & 1 & 577 \\
\hline & & 3.7162 & 2 & 115 & & & 2.5655 & 2 & -317 & 4 & 2.0326 & 2.0324 & 1 & -573 & & & 1.6844 & 2 & 866 \\
\hline \multirow[t]{5}{*}{33} & 3.717 & 3.7036 & 2 & -333 & & & 2.5636 & 1 & -227 & & & 2.0276 & 1 & 573 & & & 1.6832 & 1 & -4410 \\
\hline & & 3.6860 & 2 & 333 & 11 & 2.562 & 2.5545 & 1 & 227 & & & 2.0053 & 2 & -139 & & & 1.6739 & 1 & -1153 \\
\hline & & 3.6752 & 12 & 600 & & & 2.5519 & 1 & 317 & & & 1.9962 & 1 & -466 & 3 & 1.6683 & 1.6679 & 1 & 1153 \\
\hline & & 3.6434 & 2 & -134 & & & 2.5489 & 1 & -155 & & & 1.9941 & 1 & -755 & & & 1.6655 & 1 & -1242 \\
\hline & & 3.6359 & 1 & 134 & & & 2.5456 & 2 & 155 & & & 1.9925 & 1 & -375 & & & 1.6532 & 1 & -668 \\
\hline \multirow[t]{3}{*}{3} & 3.555 & 3.5268 & 3 & 025 & & & 2.5373 & 3 & -822 & 12 & 1.9960 & 1.9879 & 1 & 375 & & & 1.6448 & 1 & 668 \\
\hline & & 3.4380 & 2 & -531 & & & 2.5338 & 1 & 460 & & & 1.9849 & 1 & -481 & 4 & 1.6463 & 1.6363 & 1 & -1313 \\
\hline & & 3.4302 & 1 & 531 & & & 2.5273 & 2 & 822 & & & 1.9834 & 2 & 755 & & & 1.6348 & 1 & 4100 \\
\hline \multirow[t]{4}{*}{5} & 3.399 & 3.3977 & 1 & -243 & & & 2.5120 & 1 & -246 & & & 1.9823 & 3 & -1111 & & & & & \\
\hline & & 3.3805 & 1 & 440 & 10 & 2.512 & 2.5046 & 1 & 246 & & & 1.9789 & 3 & 1111 & & & & & \\
\hline & & 3.3770 & 2 & 620 & & & 2.4986 & 3 & -553 & & & & & & & & & & \\
\hline & & 3.3311 & 4 & -621 & & & 2.4896 & 3 & 553 & & & & & & & & & & \\
\hline \multirow[t]{2}{*}{7} & 3.339 & 3.3272 & 1 & 441 & & & 2.4744 & 1 & -137 & & & & & & & & & & \\
\hline & & 3.3225 & 2 & 621 & & & & & & & & & & & & & & & \\
\hline
\end{tabular}




\subsection{Single Crystal X-ray Diffraction}

A tabular fragment of paddlewheelite was chosen for the single-crystal X-ray diffraction study. Data were collected using MoK $\alpha$ X-rays from a microfocus source and an Apex II CCD-based detector mounted to a Bruker Apex II Quazar three-circle diffractometer (Bruker, Billerica, MA, USA). The Apex 3 software package (Bruker, Billerica, MA, USA) was used for processing collected diffraction data, including corrections for background, polarization, and Lorentz effects. A multi-scan semi-empirical absorption correction was done using SADABS [22] (Bruker, Billerica, MA, USA), and an initial model in the space group $P 2_{1} / c$ was suggested via SHELXT [23]. Refinements in $P 2_{1} / c$ provided a partially reasonable model, but with high $R_{1}(14 \%)$ and $w R$ factors $(\sim 28 \%)$. It also exhibits strong site splitting and yields many non-positive definite atoms with strongly prolate $U$ atoms. Closer inspection of the data revealed that reflections suffered from overlap related to pseudo-merohedral twinning. An additional starting model check was made using the Superflip algorithm [24] provided within Jana 2006 (Department of Structure Analysis, Institute of Physics, Praha, Czech Republic) [25], and symmetry element statistics indicated absence of the $2_{1}$ screw axis. The structure solution in the non-centrosymmetric space group Pc provided by SHELXT located most of the model constituents and additional $\mathrm{C}$ and $\mathrm{O}$ atoms of water were located using difference Fourier maps. We proceeded with refinement in $P c$ on the basis of $F^{2}$ with SHELXL [26], using a twin law related to inversion of the two domains about the monoclinic axis $(-100 / 0-10 / 001)$, which lowered the $R_{1}$ factor by $\sim 7 \%$. The final model included anisotropic displacement parameters for atoms except $\mathrm{O}$ and $\mathrm{C}$, and also includes minimal restraints for several misbehaving $\mathrm{C}$ atoms $(\mathrm{C} 2, \mathrm{C} 17, \mathrm{C} 18)$ and the $\mathrm{Cu} 3$ atom. $\mathrm{O}$ atoms of water molecules are strongly disordered and their occupancy was set manually based on site scattering refinement trials for these atoms. Details regarding the data collection and final refinement results are given in Table 3 . The atomic coordinates, equivalent displacement parameters, and cation bond-valence sums (BVS) are given in Table S1, anisotropic displacement parameters in Table S2, and selected interatomic distances in Table S3. Hydrogen atoms could not be located and thus detailed discussion regarding hydrogen bonding interactions is not made.

Table 3. Data collection and structure refinement details for paddlewheelite.

\begin{tabular}{ll}
\hline \multicolumn{1}{c}{ Diffractometer } & \multicolumn{1}{c}{ Bruker Quazar II with Apex II detector } \\
\hline X-ray radiation/power & $\mathrm{MoK} \alpha(\lambda=0.71075 \AA) / 50 \mathrm{kV}, 60 \mathrm{~mA}$ \\
Temperature & $120(2) \mathrm{K}$ \\
Structural Formula & $\mathrm{C}_{12} \mathrm{MgCa}_{5} \mathrm{Cu}_{2} \mathrm{U}_{4} \mathrm{O}_{77.12}$ \\
Space group & $P c$ \\
Unit cell dimensions & $a=22.052(4) \AA$ \\
& $b=17.118(3) \AA$ \\
& $c=19.354(3) \AA$ \\
$\beta$ & $90.474(2)^{\circ}$ \\
$V$ & $7306(2) \AA^{3}$ \\
$Z$ & 4 \\
Density (for above formula) & $2.438 \mathrm{~g} \cdot \mathrm{cm}^{-3}$ \\
Absorption coefficient & $9.900 \mathrm{~mm}^{-1}$ \\
$F(000)$ & 4908 \\
Crystal size & $5 \times 40 \times 50 \mu \mathrm{m}$ \\
$\theta \rho \alpha v \gamma \varepsilon$ & 1.052 to $25.218^{\circ}$ \\
Index ranges & $-26 \leq h \leq 26,-20 \leq k \leq 20,-23 \leq l \leq 23$ \\
Reflections collected/unique & $73,516 / 26,012 ; R_{\text {int }}=0.0963$ \\
Reflections with $I_{\text {obs }}>2 \sigma(I)$ & 17,626 \\
Completeness to $\theta^{\circ}{ }_{\text {full }}$ & $100 \%$ \\
Parameters (restraints) & $997(9)$ \\
GoF(obs/all) & $1.017 / 1.017$ \\
$R_{\text {obs }}$ w $w R_{\text {obs }}$ & $0.0706,0.1573$ \\
\hline &
\end{tabular}


Table 3. Cont.

\begin{tabular}{|c|c|}
\hline Diffractometer & Bruker Quazar II with Apex II detector \\
\hline$R_{\text {all }}, w R_{\text {all }}$ & $0.1136,0.1833$ \\
\hline Twin component $(\%)$ & $100 / 0-10 / 00-1(14.07(21))$ \\
\hline Largest diff. peak/hole & $+4.08 /-2.88$ e $\AA^{-3}$ \\
\hline
\end{tabular}

\subsection{Description of the structure}

The asymmetric unit of paddlewheelite is very large, containing 219 atoms; including $8 \mathrm{U}, 4 \mathrm{Cu}$, $10 \mathrm{Ca}, 2 \mathrm{Mg}, 171 \mathrm{O}$, and $24 \mathrm{C}$ atoms. Each $\mathrm{U}$ atom is bound by two multiply bonded apical ' $\mathrm{yl}^{\prime}$ oxygen atoms $\left(\mathrm{O}_{\mathrm{yl}}\right)$, forming the approximately linear uranyl cation $\left(\mathrm{UO}_{2}\right)^{2+}$. The uranyl cation is coordinated six-fold equatorially by oxygen atoms of three bidentate $\mathrm{CO}_{3}{ }^{2-}$ groups, forming a hexagonal bipyramidal uranyl tricarbonate unit (UTC). The 10 unique $\mathrm{Ca}^{2+}$ cations occur as several shapes of polyhedra from seven- to eight-coordinated. Atoms Ca1 and Ca2 are eight-coordinate slightly distorted cubes, and each share two $\mathrm{O}^{2-}$ atoms from edges of four UTC units forming quadruplet "paddlewheel" units (Figure 5). One result of this odd cubic geometry is the occurrence of a bond valence anomaly at the Ca1 and Ca2 sites, whereby their bond valence sums are higher than expected at 2.42 v.u. each. The oxygen atoms are three-coordinated (effective ionic radius $=1.36 \AA$ ) to $C a, C$, and $\mathrm{U}$, and for eight-coordinate $\mathrm{Ca}$ (effective ion radius $=1.12 \AA$ ) we expect an average $\mathrm{Ca}-\mathrm{O}$ bond length of $2.48 \AA$ [27]. The average Ca-O bond lengths from the refinement are smaller, at $2.40 \AA$ for both Ca1 and $\mathrm{Ca} 2$, hence the higher calculated valence sum. This is likely caused by bond inflexibility (U-O and $\mathrm{C}-\mathrm{O}$ ) associated with tight $\mathrm{U}$ - and C-polyhedral packing surrounding the cubic calcium site, although several $\mathrm{U}$ atoms also display similarly high valence sums.
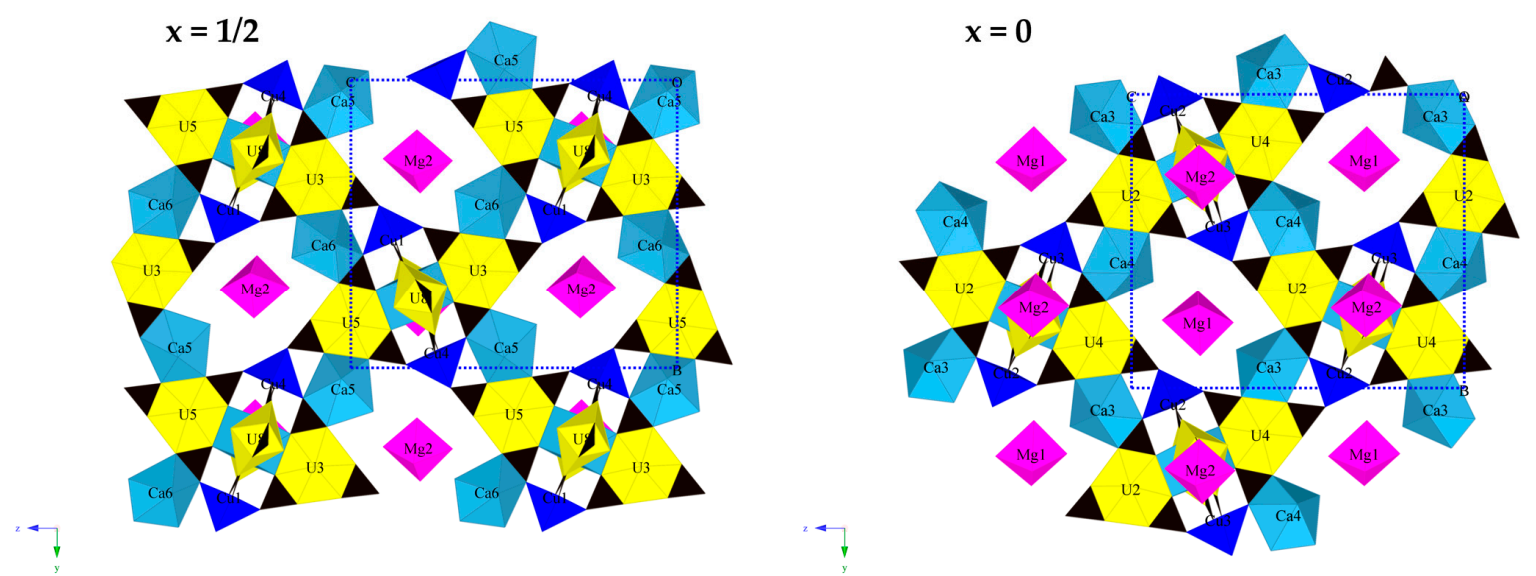

Figure 5. The structure of paddlewheelite, as viewed along [100]. Two unique sheets of paddlewheels occur at $\mathrm{x}=\frac{1}{2}$ (left) and $\mathrm{x}=0$ (right). Uranium (yellow), copper (blue), calcium (light blue), magnesium (magenta), carbon (black). Unit cell is indicated by dashed blue lines.

Two paddles (two UTC units) from each wheel form the planarity of the sheet, and 7-coordinated $\mathrm{Ca} 3, \mathrm{Ca} 4, \mathrm{Ca}$, and $\mathrm{Ca} 6$ atoms connect paddlewheels together into an open-topology type sheet. These same $\mathrm{Ca}$ atoms bond to three $\mathrm{H}_{2} \mathrm{O}$ groups, and share one edge with a $\mathrm{CO}_{3}{ }^{2-}$ triangle of one UTC unit, and one edge with a second UTC unit. Atoms Ca7, Ca8, Ca9, and Ca10 are seven- or eight-coordinated and each share one edge of a paddle that extends between sheets, and also bonds to five or six $\mathrm{H}_{2} \mathrm{O}$ groups. Magnesium cations are octahedrally coordinated and sit within pores between paddlewheels in the sheet above, such that one $\mathrm{Mg}$ cation coordinates to one paddlewheel unit.

Two unique sheets of paddlewheels are centered at $x=\frac{1}{2}$ and $x=0$ (Figure 5). The two sheets are nearly identical except that paddlewheels in each exhibit slight rotational differences; paddles at $x=0$ 
defined by U2, U4, U6, and U7 atoms are rotated $~ 5$ degrees along the "axle" axis of two Cu cations with respect to paddlewheels at $x=\frac{1}{2}$. This close similarity likely results in the strong pseudosymmetry observed during refinement, and in particular it explains the strong splitting disorder observed in the $P 2_{1} / c$ setting, which contains several unfavorably twisted carbonate units that significantly skewed the planarity of the UTC units, whereby two carbonate oxygen atoms bound to uranium were forced slightly up and down (D3h $\rightarrow$ C3 distortion). Computational studies performed using perturbation theory calculations show that by distorting UTC units in this manner produces a less stable structure [28], and may explain the symmetry lowering observed in paddlewheelite. As evidenced by the bond valence sum anomalies for $\mathrm{Ca} 1$ and $\mathrm{Ca} 2$, paddlewheels experience geometrical constraints due to the bond inflexibility of carbonate units, cubic $\mathrm{Ca}$ and the $\mathrm{Cu}$ "axle" cations, which lead to twisting of $\mathrm{Cu}$ and UTC polyhedra that breaks $2_{1}$ screw axis symmetry.

Curiously, there is no direct contact between paddlewheels of different sheets, which are held together through hydrogen bonding interactions only. Interstitial space between sheets is filled by many disordered $\mathrm{H}_{2} \mathrm{O}$ groups that form hydrogen bonds with $\mathrm{O}_{\mathrm{yl}}$ atoms and the $\mathrm{H}_{2} \mathrm{O}$ groups bound to $\mathrm{Ca}$ and $\mathrm{Mg}$ cations. In total there are $22 \mathrm{H}_{2} \mathrm{O}$ groups bound to cations. Each Ca site has a variable number of coordinating $\mathrm{H}_{2} \mathrm{O}$ groups, from 3 to $\sim 6(\mathrm{Ca} 8)$, while each $\mathrm{Mg}$ binds to $5 \mathrm{H}_{2} \mathrm{O}$ groups. Thus, an idealized formula that more accurately depicts the distribution of $\mathrm{H}_{2} \mathrm{O}$ groups in the structure of paddlewheelite is $\mathrm{Mg}\left(\mathrm{H}_{2} \mathrm{O}\right)_{5} \mathrm{Ca}_{5}\left(\mathrm{H}_{2} \mathrm{O}\right)_{17} \mathrm{Cu}_{2}\left[\left(\mathrm{UO}_{2}\right)\left(\mathrm{CO}_{3}\right)_{3}\right]_{4} \cdot 11 \mathrm{H}_{2} \mathrm{O}$.

\section{Discussion}

$\mathrm{Cu}^{2+}$ oxysalt minerals exhibit a large range of structural configurations due to the diversity of $\mathrm{Cu}^{2+}$ coordination geometries; six-coordinated octahedral, five-coordinated square-pyramidal and triangular-bipyramidal, and four-coordinated square-planar geometries [29]. Octahedral coordination is the most common and is characterized by a strong distortion originating from electronic instability of the $d^{9}$ configuration of $\mathrm{Cu}^{2+}$ in an octahedral ligand-field. This electronic instability is explained by the Jahn-Teller theorem [30], which also gave its name to the distortion affecting the $\mathrm{Cu} \varphi_{6}$ octahedra (Jahn-Teller distortion). Octahedral $\mathrm{Cu}^{2+}$ occurs as either compressed $(2+4)$ or elongated $(4+2) \mathrm{Cu} \varphi_{6}$ polyhedra; however, the latter configuration is favored by second-order Jahn-Teller mixing of $3 d$ and $4 s$ orbitals [31], and this is by far the most common configuration observed in minerals, including $\mathrm{Cu}$-containing uranyl minerals (Table 4). Prior to the description of paddlewheelite, only two uranyl minerals were known to contain square pyramidal coordinated $\mathrm{Cu}^{2+}$, vandenbrandeite and pseudojohannite, as well as a $\mathrm{Cu}^{2+}$-bearing variety of rabejacite from Jáchymov [32]. In vandenbrandeite, dimers of edge sharing $\mathrm{Cu} \varphi_{5}$ square pyramids, with apical $\mathrm{O}$ anions oriented in opposite directions, connect to $\mathrm{UO}_{7}$ polyhedra by corner and edge-sharing forming a sheet (Figure 6). A similar arrangement of $\mathrm{Cu} \varphi_{5}$ square pyramids is found in $\mathrm{Cu}^{2+}$-rabejacite, where dimers of distorted square pyramidal $\mathrm{Cu}^{2+}$ and $\mathrm{Ca}^{2+}$-polyhedra are mutually interconnected through vertex-sharing, forming a sheet-like interlayer structure. In pseudojohannite, chains of highly elongated $(4+2) \mathrm{Cu} \varphi_{6}$ octahedra connect dimers of edge sharing $\mathrm{Cu} \varphi_{5}$ square pyramids. The chains in pseudojohannite are isolated and only connect to uranyl sulfate sheets via hydrogen-bonds, whereas each of the four $\mathrm{Cu}^{2+}$ cations in paddlewheelite adopt an isolated square pyramidal geometry by sharing five $\mathrm{O}^{2-}$ from five $\mathrm{CO}_{3}{ }^{2-}$ triangles. In paddlewheelite, four uranyl tricarbonate clusters bind to the bases of two $\mathrm{Cu}$ square pyramids by sharing corners with carbonate triangles, forming the "axle" to each paddlewheel, and centered by the cubic calcium "gearbox." The apical $\mathrm{O}$ atom of each $\mathrm{Cu}$ square pyramid is the same corner $\mathrm{O}$ atom of $\mathrm{CO}_{3}{ }^{2-}$ from an adjacent UTC paddle in the sheet. 
Table 4. List of $\mathrm{Cu}^{2+}$-bearing uranyl minerals containing Jahn-Teller distorted $\mathrm{Cu}^{2+} \varphi_{\mathrm{n}}$ polyhedra $\{\mathrm{O}=$ $(4+2)$ octahedron; $\mathrm{SP}=$ square pyramid $\}$.

\begin{tabular}{|c|c|c|c|c|c|}
\hline Mineral & $\begin{array}{l}\text { Distortion } \\
\text { Type }\end{array}$ & $\begin{array}{c}\text { Avg. } \\
\mathrm{Cu}-\mathrm{O}_{e q}(\AA)\end{array}$ & $\begin{array}{c}\text { Avg. } \\
\mathrm{Cu}-\mathrm{O}_{a p}(\AA)\end{array}$ & $\begin{array}{c}\mathrm{Cu} \varphi_{\mathrm{n}} \\
\text { Connectivity }\end{array}$ & Ref. \\
\hline $\begin{array}{c}\text { Torbernite } \\
\mathrm{Cu}\left[\left(\mathrm{UO}_{2}\right)\left(\mathrm{PO}_{4}\right)\right]_{2} \cdot 12 \mathrm{H}_{2} \mathrm{O}\end{array}$ & $\mathrm{O}$ & 1.913 & 2.556 & isolated & [33] \\
\hline $\begin{array}{c}\text { zeunerite } \\
\mathrm{Cu}\left[\left(\mathrm{UO}_{2}\right)\left(\mathrm{AsO}_{4}\right)\right]_{2} \cdot 12 \mathrm{H}_{2} \mathrm{O}\end{array}$ & $\mathrm{O}$ & 1.929 & 2.482 & isolated & [33] \\
\hline $\begin{array}{c}\text { ulrichite } \\
\mathrm{Ca}\left[\mathrm{Cu}\left(\mathrm{UO}_{2}\right)\left(\mathrm{PO}_{4}\right)_{2}\right] \cdot 4 \mathrm{H}_{2} \mathrm{O}\end{array}$ & $\mathrm{O}$ & 1.943 & 2.65 & isolated & [34] \\
\hline $\begin{array}{c}\text { sengierite } \\
\mathrm{Cu}_{2}\left[\left(\mathrm{UO}_{2}\right)_{2}\left(\mathrm{~V}_{2} \mathrm{O}_{8}\right)\right](\mathrm{OH})_{2} \cdot 6 \mathrm{H}_{2} \mathrm{O}\end{array}$ & $\mathrm{O}$ & 1.956 & 2.507 & dimer & [35] \\
\hline $\begin{array}{l}\text { demesmaekerite } \\
\mathrm{Pb}_{2} \mathrm{Cu}_{5}\left[\left(\mathrm{UO}_{2}\right)\left(\mathrm{SeO}_{3}\right)_{3}\right]_{2}(\mathrm{OH})_{6} \cdot 2 \mathrm{H}_{2} \mathrm{O}\end{array}$ & $\begin{array}{c}\mathrm{O} \\
\mathrm{O}(2+4)\end{array}$ & $\begin{array}{l}1.993 \\
2.212\end{array}$ & $\begin{array}{l}2.378 \\
1.927\end{array}$ & sheet & [36] \\
\hline $\begin{array}{c}\text { derriksite } \\
\mathrm{Cu}_{4}\left[\left(\mathrm{UO}_{2}\right)\left(\mathrm{SeO}_{3}\right)_{2}\right]_{2}(\mathrm{OH})_{6}\end{array}$ & $\mathrm{O}$ & 1.970 & 2.385 & sheet & [37] \\
\hline $\begin{array}{l}\text { marthozite } \\
\mathrm{Cu}\left[\left(\mathrm{UO}_{2}\right)_{3}\left(\mathrm{SeO}_{3}\right)_{2} \mathrm{O}_{2}\right] \cdot 8 \mathrm{H}_{2} \mathrm{O}\end{array}$ & $\mathrm{O}$ & 1.987 & 2.381 & isolated & [38] \\
\hline $\begin{array}{c}\text { johannite } \\
\mathrm{Cu}\left[\left(\mathrm{UO}_{2}\right)_{2}\left(\mathrm{SO}_{4}\right)_{2}(\mathrm{OH})_{2}\right] \cdot 8 \mathrm{H}_{2} \mathrm{O}\end{array}$ & $\mathrm{O}$ & 1.969 & 2.397 & isolated & [39] \\
\hline $\begin{array}{c}\text { deloryite } \\
\mathrm{Cu}_{4}\left[\left(\mathrm{UO}_{2}\right)\left(\mathrm{Mo}_{2} \mathrm{O}_{8}\right)\right](\mathrm{OH})_{6}\end{array}$ & $\mathrm{O}$ & 2.003 & 2.288 & sheet & [40] \\
\hline $\begin{array}{c}\text { roubaultite } \\
{\left[\mathrm{Cu}_{2}\left(\mathrm{UO}_{2}\right)_{3}\left(\mathrm{CO}_{3}\right)_{2} \mathrm{O}_{2}(\mathrm{OH})_{2}\right] \cdot 8 \mathrm{H}_{2} \mathrm{O}}\end{array}$ & $\mathrm{O}$ & 1.969 & 2.507 & chain & [41] \\
\hline $\begin{array}{l}\text { cuprosklodowskite } \\
\mathrm{Cu}\left[\left(\mathrm{UO}_{2}\right)\left(\mathrm{SiO}_{3}(\mathrm{OH})\right)\right]_{2} \cdot 6 \mathrm{H}_{2} \mathrm{O}\end{array}$ & $\mathrm{O}$ & 1.937 & 2.443 & isolated & [42] \\
\hline $\begin{array}{l}\text { vandenbrandeite } \\
{\left[\left(\mathrm{UO}_{2}\right) \mathrm{Cu}(\mathrm{OH})_{4}\right]}\end{array}$ & $\mathrm{SP}$ & 1.945 & 2.601 & dimer & [43] \\
\hline $\begin{array}{c}\mathrm{Cu}^{2+} \text {-rabejacite } \\
\left(\mathrm{Ca}_{1.56} \mathrm{Cu}_{0.40}\right) \sum_{1.90}\left[\left(\mathrm{UO}_{2}\right)_{4} \mathrm{O}_{4}\left(\mathrm{SO}_{4}\right)_{2}\right] \cdot 8 \mathrm{H}_{2} \mathrm{O}\end{array}$ & SP & 2.005 & 2.320 & dimer & [32] \\
\hline pseudojohannite & $\mathrm{O}$ & 1.970 & 2.538 & & \\
\hline $\mathrm{Cu}_{3}(\mathrm{OH})_{2}\left[\left(\mathrm{UO}_{2}\right)_{4} \mathrm{O}_{4}\left(\mathrm{SO}_{4}\right)_{2}\right] \cdot 12 \mathrm{H}_{2} \mathrm{O}$ & SP & 1.954 & 2.426 & chain & [44] \\
\hline $\begin{array}{c}\text { paddlewheelite } \\
\mathrm{MgCa}_{5} \mathrm{Cu}_{2}\left[\left(\mathrm{UO}_{2}\right)\left(\mathrm{CO}_{3}\right)_{3}\right]_{4} \cdot 33 \mathrm{H}_{2} \mathrm{O}\end{array}$ & SP & 1.960 & 2.205 & isolated & - \\
\hline
\end{tabular}
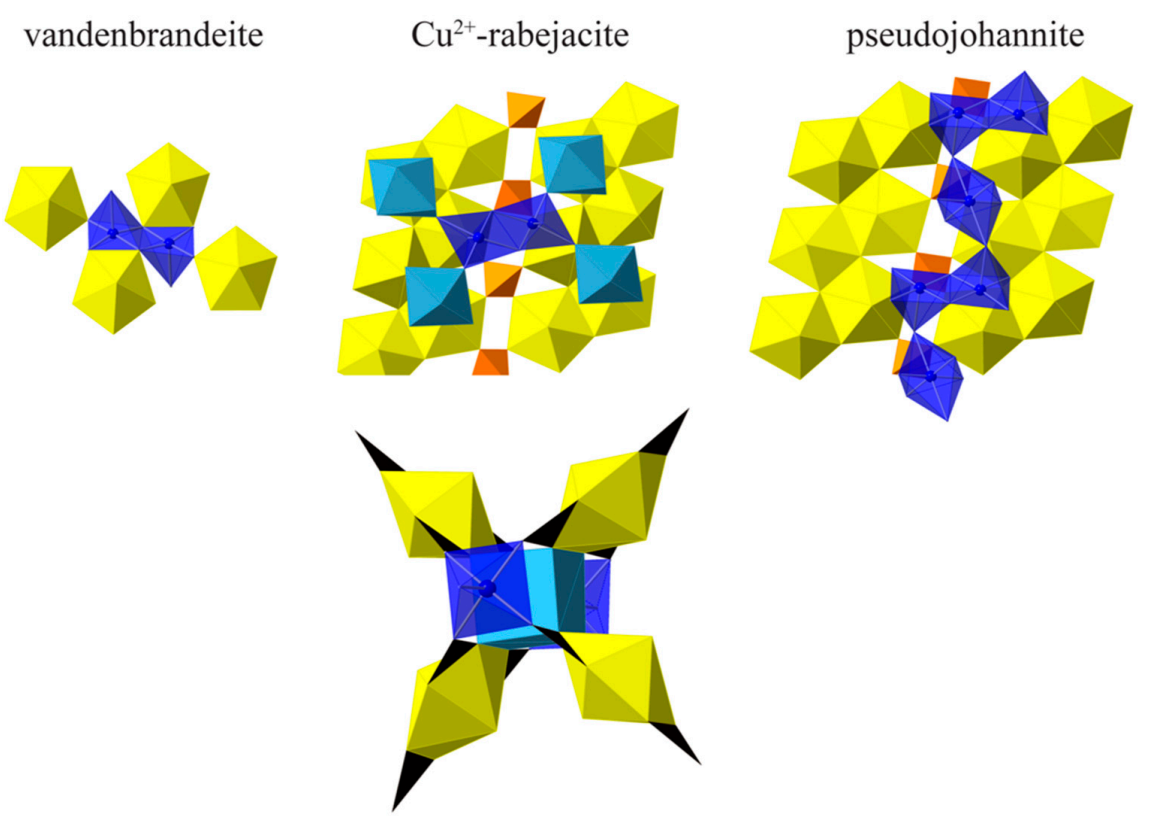

paddlewheelite

Figure 6. A comparison of $\mathrm{Cu}^{2+}$ geometries in $\mathrm{Cu}$-containing uranyl minerals with square pyramidal geometries. Uranium (yellow), calcium (light blue), copper (blue transparent), sulfur (orange), carbon (black). 
As determined by the Krivovichev method [45], the structural complexity of paddlewheelite is very high at 3386.93 bits/unit cell, making it the second most complex uranyl carbonate mineral known after ewingite (Table 5). Paddlewheelite is a member of the uranyl carbonates with U:C $=1: 3$, Nickel-Strunz class 05.ED. Its structure bears some resemblance to other uranyl carbonate minerals with paddle-like motifs, such as braunerite [2], línekite [3], albrechtschraufite [46], and andersonite [47] (Figure 7). The UTC paddles in braunerite revolve around 4 Ca polyhedra, while línekite, albrechtschraufite, and andersonite paddles are each centered about 2 Ca polyhedra. While it is not the first uranyl carbonate mineral known to contain paddles, the arrangement of UTC units and the presence of unique geometries for $\mathrm{Ca}$ and $\mathrm{Cu}$ cations in paddlewheelite make it an interesting and complex structure that is distinct from anything yet found. Paddlewheelite contains the first example of isolated square pyramidal $\mathrm{Cu}^{2+}$ in a uranyl mineral, and as far as we know the first instance of $\mathrm{Ca}^{2+}$ in cubic coordination in a uranyl mineral. Its description encourages further exploration of the $\mathrm{Cu}-\mathrm{U}-\mathrm{CO}_{3}$ system.

Table 5. A comparison of structural complexity (bits/u.c.) between uranyl carbonate minerals.

\begin{tabular}{ccccc}
\hline Mineral & Formula & $\begin{array}{c}\text { Unit Cell } \\
\text { Volume (Å3) }\end{array}$ & $\begin{array}{c}\mathbf{I}_{\mathbf{G} \text { Total }} \\
\text { (bits/u.c.) }\end{array}$ & Ref. \\
\hline albrechtschraufite & $\mathrm{MgCa}_{4} \mathrm{~F}_{2}\left[\left(\mathrm{UO}_{2}\right)\left(\mathrm{CO}_{3}\right)_{3}\right]_{2} \cdot 17-18 \mathrm{H}_{2} \mathrm{O}$ & 1174.6 & 1020.28 & {$[46]$} \\
andersonite & $\mathrm{Na}_{2} \mathrm{Ca}\left[\left(\mathrm{UO}_{2}\right)\left(\mathrm{CO}_{3}\right)_{3}\right] \cdot 6 \mathrm{H}_{2} \mathrm{O}$ & 6544.4 & 567.38 & {$[47]$} \\
bayleyite & $\mathrm{Mg}_{2}\left[\left(\mathrm{UO}_{2}\right)\left(\mathrm{CO}_{3}\right)_{3}\right] \cdot 18 \mathrm{H}_{2} \mathrm{O}$ & 2624.4 & 1510.28 & {$[48]$} \\
braunerite & $\mathrm{K}_{2} \mathrm{Ca}\left(\mathrm{UO}_{2}\right)\left(\mathrm{CO}_{3}\right)_{3} \cdot 6-7 \mathrm{H}_{2} \mathrm{O}$ & 5958 & 2305.36 & {$[2]$} \\
čejkaite & $\mathrm{Na}_{4}\left[\left(\mathrm{UO}_{2}\right)\left(\mathrm{CO}_{3}\right)_{3}\right]$ & 963.6 & 161.42 & {$[49]$} \\
ewingite & $\mathrm{Mg}_{8} \mathrm{Ca}_{8}\left(\mathrm{UO}_{2}\right)_{24}\left(\mathrm{CO}_{3}\right)_{30} \mathrm{O}_{4}(\mathrm{OH})_{12} \cdot 138 \mathrm{H}_{2} \mathrm{O}$ & 59245 & $12,684.86$ & {$[1]$} \\
leószilárdite & $\mathrm{Na}_{6} \mathrm{Mg}_{2}\left[\left(\mathrm{UO}_{2}\right)\left(\mathrm{CO}_{3}\right)_{3}\right]_{2} \cdot 6 \mathrm{H}_{2} \mathrm{O}$ & 1189.4 & 179.33 & {$[50]$} \\
liebigite & $\mathrm{Ca}_{2}\left(\mathrm{UO}_{2}\right)\left(\mathrm{CO}_{3}\right)_{3} \cdot 11 \mathrm{H}_{2} \mathrm{O}$ & 4021.5 & 567.53 & {$[39]$} \\
línekite & $\mathrm{K}_{2} \mathrm{Ca}_{3}\left[\left(\mathrm{UO}_{2}\right)\left(\mathrm{CO}_{3}\right)_{3}\right]_{2} \cdot 8 \mathrm{H}_{2} \mathrm{O}$ & 5622 & 2140.57 & {$[3]$} \\
paddlewheelite & $\mathrm{MgCa}_{5} \mathrm{Cu}_{2}\left[\left(\mathrm{UO}_{2}\right)\left(\mathrm{CO}_{3}\right)_{3}\right]_{4} \cdot 33 \mathrm{H}_{2} \mathrm{O}$ & 7306 & 3386.93 & {$[41]$} \\
roubaultite & $\mathrm{Cu}_{2}\left(\mathrm{UO}_{2}\right)_{3}\left(\mathrm{CO}_{3}\right)_{2} \mathrm{O}_{2}\left(\mathrm{OH}_{2}\right)_{2} \cdot 4 \mathrm{H}_{2} \mathrm{O}$ & 421.02 & 156.75 & {$[51]$} \\
rutherfordine & $\left(\mathrm{UO}_{2}\right)\left(\mathrm{CO}_{3}\right)$ & 192.9 & 15.65 & {$[51]$} \\
schröckingerite & $\mathrm{NaCa}_{3}\left(\mathrm{UO}_{2}\right)\left(\mathrm{CO}_{3}\right)_{3}\left(\mathrm{SO}_{4}\right) \mathrm{F} \cdot 10 \mathrm{H}_{2} \mathrm{O}$ & 1151.29 & 578.59 & {$[52]$} \\
swartzite & $\left.\mathrm{CaMg}^{2}\left(\mathrm{UO}_{2}\right)\left(\mathrm{CO}_{3}\right)_{3}\right] \cdot 12 \mathrm{H}_{2} \mathrm{O}$ & 1029.94 & 527.16 & {$[53]$} \\
\hline
\end{tabular}

paddlewheelite
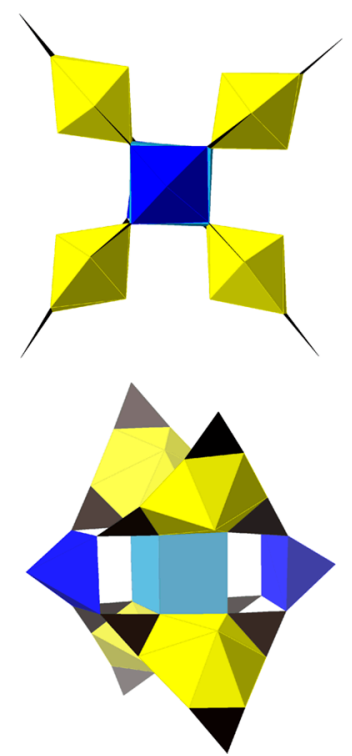

braunerite
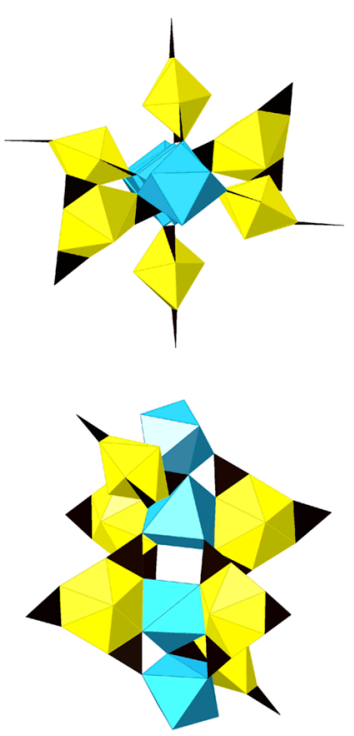

línekite
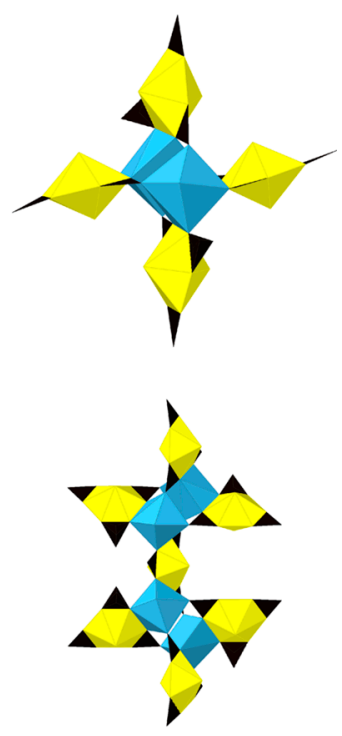

Figure 7. A comparison of the paddles in paddlewheelite, braunerite, and línekite. 
Chemically, paddlewheelite is related to voglite [10,54], $\mathrm{Ca}_{2} \mathrm{Cu}\left(\mathrm{UO}_{2}\right)\left(\mathrm{CO}_{3}\right)_{4} \cdot 6 \mathrm{H}_{2} \mathrm{O}$, a very rare mineral that remains poorly characterized and has an unknown crystal structure. Piret and Deliens [9] report a monoclinic $\left(P 2_{1} / m\right.$ or $\left.P 2_{1}\right)$ cell with large unit cell volume $\sim 6605 \AA^{3}$, however, based on the results of Ondruš et al. [10], voglite does not contain essential Mg as in paddlewheelite. It is possible that voglite may share some structural similarities to paddlewheelite, including square pyramidal copper polyhedra and a paddle-like arrangement of UTC units surrounding calcium cations, but more work is required.

Supplementary Materials: The following are available online at http:/ / www.mdpi.com/2075-163X/8/11/511/s1, Table S1. Atomic coordinates, displacement parameters $\left(\AA^{2}\right)$, and bond valence sums for paddlewheelite; Table S2. Anisotropic atomic displacement parameters $\left(\AA^{2}\right)$ for paddlewheelite; Table S3; Selected bond distances (in $\AA$ ) for paddlewheelite.

Author Contributions: T.A.O. and J.P. collected the new mineral and conceptualized the work. T.A.O. obtained the crystallographic, spectroscopic, anl authors provided structural insights and helped to write, revise, and edit the manuscript. P.C.B., A.R.K., and J.P. ad chemical data, and wrote the original draft. A.R.K. provided optical and powder diffraction measurements. Alcquired the funding used for this study.

Funding: Support for this work is provided by the Chemical Sciences, Geosciences and Biosciences Division, Office of Basic Energy Sciences, Office of Science, U.S. Department of Energy, Grant No. DE-FG02-07ER15880. A portion of this study was funded by the John Jago Trelawney Endowment to the Mineral Sciences Department of the Natural History Museum of Los Angeles County. Jakub Plášil is thankful for the support from project No. LO1603 under the Ministry of Education, Youth and Sports National sustainability program I of the Czech Republic.

Acknowledgments: We thank three anonymous reviewers for valuable comments, as well as those from members of the Commission on New Minerals, Nomenclature and Classification that improved the quality of this manuscript. We also thank the ND Energy Materials Characterization Facility for use of the single crystal X-ray diffraction instrument. The Element2 HR-ICP-MS instrument used for chemical analyses is housed within the Midwest Isotope and Trace Element Research Analytical Center (MITERAC) at the University of Notre Dame.

Conflicts of Interest: The authors declare no conflict of interest.

\section{References}

1. Olds, T.A.; Plášil, J.; Kampf, A.R.; Simonetti, A.; Sadergaski, L.R.; Chen, Y.-S.; Burns, P.C. Ewingite: Earth's most complex mineral. Geology 2017, 45, 1007-1010. [CrossRef]

2. Plášil, J.; Mereiter, K.; Kampf, A.R.; Hloušek, J.; Škoda, R.; Čejka, J.; Němec, I.; Ederová, J. New minerals and nomenclature modifications approved in 2016. Mineral. Mag. 2016, 80, 691-697.

3. Plášil, J.; Čejka, J.; Sejkora, J.; Hloušek, J.; Škoda, R.; Novák, M.; Dušek, M.; Cisařová, I.; Němec, I.; Ederová, J. Línekite, $\mathrm{K}_{2} \mathrm{Ca}_{3}\left[\left(\mathrm{UO}_{2}\right)\left(\mathrm{CO}_{3}\right)_{3}\right]_{2} \cdot 8 \mathrm{H}_{2} \mathrm{O}$, a new uranyl carbonate mineral from Jachymov, Czech Republic. J. Geosci. 2017, 62, 201-213. [CrossRef]

4. Burns, P.C. $\mathrm{U}^{6+}$ minerals and inorganic compounds: Insights into an expanded structural hierarchy of crystal structures. Can. Min. 2005, 43, 1839-1894. [CrossRef]

5. Lussier, A.J.; Burns, P.C.; King-Lopez, R. A revised and expanded structure hierarchy of natural and synthetic hexavalent uranium compounds. Can. Min. 2016, 54, 177-283. [CrossRef]

6. Langmuir, D. Uranium solution-mineral equilibria at low temperatures with applications to sedimentary ore deposits. Geochim. Cosmochim. Acta 1978, 42, 547-569. [CrossRef]

7. Clark, D.L.; Hobart, D.E.; Neu, M.P. Actinide Carbonate Complexes and Their Importance in Actinide Environmental Chemistry. Chem. Rev. 1995, 95, 25-48. [CrossRef]

8. Plášil, J. Oxidation-hydration weathering of uraninite: The current state-of-knowledge. J. Geosci 2014, 59, 99-114. [CrossRef]

9. Piret, P.; Deliens, M. New crystal data for $\mathrm{Ca}, \mathrm{Cu}, \mathrm{UO}_{2}$ hydrated carbonate: Voglite. J. Appl. Crystallogr. 1979, 12, 616. [CrossRef]

10. Ondruš, P.; Veselovský, F.; Hloušek, J.; Skála, R.; Šrein, V.; Vavřin, I.; Frýda, J.; Čejka, J.; Gabašová, A. Secondary minerals of the Jáchymov (Joachimsthal) ore district. J. Czech Geol. Soc. 1997, 42, 3-76.

11. Ondruš, P.; Veselovský, F.; Gabašová, A.; Hloušek, J.; Šrein, V.; Vavřin, I.; Skála, R.; Sejkora, J.; Drábek, M. Primary minerals of the Jáchymov ore district. J. Czech Geol. Soc. 2003, 48, 19-147.

12. Tvrdý, J.; Plášil, J. Reiche Erzlagerstätte und Radonbad im böhmischen Westerzgebirge. Aufschluss 2010, 61, 277-292. 
13. Hloušek, J.; Plášil, J.; Sejkora, J.; Škácha, P. News and new minerals from Jáchymov, Czech Republic (2003-2014). Bull. Mineral.-Petrol. Odd. Nár. Muz. 2014, 22, 155-181.

14. Larsen, E.S. The Microscopic Determination of the Nonopaque Minerals, Bulletin 679 ed.; U.S. Geological Survey: Reston, VA, USA, 1921.

15. Mandarino, J.A. The Gladstone-Dale relationship: Part IV. The compatiblity concept and its application. Can. Mineral. 1981, 19, 441-450.

16. Čejka, J. Infrared spectroscopy and thermal analysis of the uranyl minerals. In Uranium: Mineralogy, Geochemistry and the Environment; Burns, P.C., Ewing, R.C., Eds.; Mineralogical Society of America: Washington, DC, USA, 1999; Volume 38, pp. 521-622.

17. Libowitzky, E. Correlation of $\mathrm{O}-\mathrm{H}$ stretching frequencies and $\mathrm{O}-\mathrm{H} \cdots \mathrm{O}$ hydrogen bond lengths in minerals. Mon. Chem. 1999, 130, 1047-1059. [CrossRef]

18. Bartlett, J.R.; Cooney, R.P. On the determination of uranium-oxygen bond lengths in dioxouranium(VI) compounds by Raman spectroscopy. J. Mol. Struct. 1989, 193, 295-300. [CrossRef]

19. Pouchou, J.L.; Pichoir, F. "PAP" $(\phi \rho Z)$ procedure for improved quantitative microanalysis. In Microbeam Analysis; Armstrong, J.T., Ed.; San Francisco Press: San Francisco, CA, USA, 1985; pp. 104-106.

20. Stubbs, J.E.; Veblen, L.A.; Elbert, D.C.; Zachara, J.M.; Davis, J.A.; Veblen, D.R. Newly recognized hosts for uranium in the Hanford Site vadose zone. Geochim. Cosmochim. Acta 2009, 73, 1563-1576. [CrossRef]

21. Plášil, J.; Sejkora, J.; Čejka, J.; Škoda, R.; Goliáš, V. Supergene mineralization of the Medvědín uranium deposit, Krkonoše Mountains, Czech Republic. J. Geosci. 2009, 54, 15-56. [CrossRef]

22. Krause, L.; Herbst-Irmer, R.; Sheldrick, G.M.; Stalke, D. Comparison of silver and molybdenum microfocus X-ray sources for single-crystal structure determination. J. Appl. Crystallogr. 2015, 48, 3-10. [CrossRef] [PubMed]

23. Sheldrick, G.M. SHELXT-Integrated space-group and crystal-structure determination. Acta Crystallogr. Sect. A 2015, 71, 3-8. [CrossRef] [PubMed]

24. Palatinus, L.; Chapuis, G. SUPERFLIP-A computer program for the solution of crystal structures by charge flipping in arbitrary dimensions. J. Appl. Crystallogr. 2007, 40, 786-790. [CrossRef]

25. Petříček, V.; Dušek, M.; Palatinus, L. Crystallographic Computing System JANA2006: General features. Z. Kristall. 2014, 229, 345-352. [CrossRef]

26. Sheldrick, G. Crystal structure refinement with SHELXL. Acta Crystallogr. Sect. C 2015, 71, 3-8. [CrossRef] [PubMed]

27. Shannon, R.D.; Prewitt, C.T. Effective ionic radii in oxides and fluorides. Acta Crystallogr. Sect. B 1969, 25, 925-946. [CrossRef]

28. Gagliardi, L.; Grenthe, I.; Roos, B.O. A Theoretical Study of the Structure of Tricarbonatodioxouranate. Inorg. Chem. 2001, 40, 2976-2978. [CrossRef] [PubMed]

29. Burns, P.C.; Hawthorne, F.C. Static and dynamic Jahn-Teller effects in $\mathrm{Cu}^{2+}$ oxysalt minerals. Can. Min. 1996, 34, 1089-1105.

30. Jahn, H.A.; Teller, E. Stability of polyatomic molecules in degenerate electronic states I-Orbital degeneracy. Proc. R. Soc. Lond. A Math. Phys. Sci. 1937, 161, 220. [CrossRef]

31. Deeth, R.J. The ligand field molecular mechanics model and the stereoelectronic effects of $d$ and s electrons. Coord. Chem. Rev. 2001, 212, 11-34. [CrossRef]

32. Plášil, J.; Dušek, M.; Čejka, J.; Sejkora, J. The crystal structure of rabejacite, the $\mathrm{Ca}^{2+}$-dominant member of the zippeite group. Mineral. Mag. 2014, 78, 1249-1264. [CrossRef]

33. Locock, A.J.; Burns, P.C. Crystal structures and synthesis of the copper-dominant members of the autunite and meta-autunite groups: Torbernite, zeunerite, metatorbernite and metazeunerite. Can. Min. 2003, 41, 489-502. [CrossRef]

34. Kolitsch, U.; Giester, G. Revision of the crystal structure of ulrichite, $\mathrm{CaCu}^{2+}\left(\mathrm{UO}_{2}\right)\left(\mathrm{PO}_{4}\right)_{2} \cdot 4 \mathrm{H}_{2} \mathrm{O}$. Mineral. Mag. 2001, 65, 717-724. [CrossRef]

35. Piret, P.; Declercq, J.P.; Wautersstoop, D. Crystal-structure of sengierite. Bull. Minéral. 1980, 103, $176-178$.

36. Ginderow, D.; Cesbron, F. Structure of demesmaekerite, $\mathrm{Pb}_{2} \mathrm{Cu}_{5}\left(\mathrm{SeO}_{3}\right)_{6}\left(\mathrm{UO}_{2}\right)_{2}(\mathrm{OH})_{6} \cdot \mathrm{H}_{2} \mathrm{O}$. Acta Crystallogr. Sect. C 1983, 39, 824-827. [CrossRef]

37. Ginderow, D.; Cesbron, F. The structure of derriksite, $\mathrm{Cu}_{4}\left(\mathrm{UO}_{2}\right)\left(\mathrm{SeO}_{3}\right)_{2}(\mathrm{OH})_{6}$. Acta Crystallogr. Sect. C 1983, 39, 1605-1607. [CrossRef] 
38. Cooper, M.A.; Hawthorne, F.C. Structure topology and hydrogen bonding in marthozite, $\mathrm{Cu}^{2+}\left[\left(\mathrm{UO}_{2}\right)_{3}\left(\mathrm{SeO}_{3}\right)_{2}\right.$ $\left.\mathrm{O}_{2}\right]\left(\mathrm{H}_{2} \mathrm{O}\right)_{8}$, a comparison with guilleminite, $\mathrm{Ba}\left[\left(\mathrm{UO}_{2}\right)_{3}\left(\mathrm{SeO}_{3}\right)_{2} \mathrm{O}_{2}\right]\left(\mathrm{H}_{2} \mathrm{O}\right)_{3}$. Can. Mineral. 2001, 39, 797-807. [CrossRef]

39. Mereiter, $\mathrm{K}$. The crystal-structure of liebigite, $\mathrm{Ca}_{2} \mathrm{UO}_{2}\left(\mathrm{CO}_{3}\right)_{3} \cdot 11 \mathrm{H}_{2} \mathrm{O}$. Tscher. Mineral. Petr. Mitt. 1982, 30, 277-288. [CrossRef]

40. Pushcharovsky, D.Y.; Rastsvetaeva, R.K.; Sarp, H. Crystal structure of deloryite, $\mathrm{Cu}_{4}\left(\mathrm{UO}_{2}\right)\left[\mathrm{Mo}_{2} \mathrm{O}_{8}\right](\mathrm{OH})_{6}$. J. Alloys Compd. 1996, 239, 23-26. [CrossRef]

41. Ginderow, D.; Cesbron, F. The structure of roubaultite, $\mathrm{Cu}_{2}\left(\mathrm{UO}_{2}\right)_{3}\left(\mathrm{CO}_{3}\right)_{2} \mathrm{O}_{2}(\mathrm{OH})_{2} \cdot 4 \mathrm{H}_{2} \mathrm{O}$. Acta Crystallogr. Sect. C 1985, 41, 654-657. [CrossRef]

42. Rosenzweig, A.; Ryan, R.R. Refinement of the crystal structure of cuprosklodowskite, $\left.\mathrm{Cu}\left(\mathrm{UO}_{2}\right)_{2}\left(\mathrm{SiO}{ }_{3} \mathrm{OH}\right)_{2}\right]$. $6 \mathrm{H}_{2}$ O. Am. Mineral. 1975, 60, 448-453.

43. Rosenzweig, A.; Ryan, R.R. Vandenbrandeite $\mathrm{Cu}\left(\mathrm{UO}_{2}\right)(\mathrm{OH})_{4}$. Cryst. Struct. Commun. 1977, 6, 53-56.

44. Plášil, J. Crystal structure refinement of pseudojohannite, $\mathrm{Cu}_{3}(\mathrm{OH})_{2}\left[\left(\mathrm{UO}_{2}\right)_{4} \mathrm{O}_{4}\left(\mathrm{SO}_{4}\right)_{2}\right]\left(\mathrm{H}_{2} \mathrm{O}\right)_{12}$, from the type locality-Jachymov, Czech Republic. J. Geosci. 2015, 60, 123-127. [CrossRef]

45. Krivovichev, S. Topological complexity of crystal structures: Quantitative approach. Acta Crystallogr. Sect. A 2012, 68, 393-398. [CrossRef] [PubMed]

46. Mereiter, K. Description and crystal structure of albrechtschraufite, $\mathrm{MgCa}_{4} \mathrm{~F}_{2}\left[\mathrm{UO}_{2}\left(\mathrm{CO}_{3}\right)_{3}\right] \cdot 17-18 \mathrm{H}_{2} \mathrm{O}$. Mineral. Petrol. 2013, 107, 179-188. [CrossRef]

47. Coda, A.; Della Giusta, A.; Tazzoli, V. The Structure of Synthetic Andersonite, $\mathrm{Na}_{2} \mathrm{Ca}_{2}\left[\mathrm{UO}_{2}\left(\mathrm{CO}_{3}\right)_{3}\right] \cdot x \mathrm{H}_{2} \mathrm{O}$ (x 5.6). Acta Crystallogr. Sect. B 1981, 37, 1496-1500. [CrossRef]

48. Mayer, H.; Mereiter, K. Synthetic bayleyite, $\mathrm{Mg}_{2} \mathrm{UO}_{2}\left(\mathrm{CO}_{3}\right)_{3} \cdot 18 \mathrm{H}_{2} \mathrm{O}$-Thermochemistry, crystallography and crystal-structure. Tschermaks Mineral. Petrogr. Mitt. 1986, 35, 133-146. [CrossRef]

49. Plášil, J.; Fejfarová, K.; Dušek, M.; Škoda, R.; Rohliček, J. Revision of the symmetry and the crystal structure of čejkaite, $\mathrm{Na}_{4}\left(\mathrm{UO}_{2}\right)\left(\mathrm{CO}_{3}\right)_{3}$. Am. Mineral. 2013, 98, 549-553. [CrossRef]

50. Olds, T.A.; Sadergaski, L.R.; Plášil, J.; Kampf, A.R.; Burns, P.C.; Steele, I.M.; Marty, J.; Carlson, S.M.; Mills, O.P. Leószilárdite, the first $\mathrm{Na}, \mathrm{Mg}$-containing uranyl carbonate from the Markey Mine, San Juan County, Utah, USA. Mineral. Mag. 2017, 81, 1039-1050. [CrossRef]

51. Finch, R.J.; Cooper, M.A.; Hawthorne, F.C.; Ewing, R.C. Refinement of the crystal structure of rutherfordine. Can. Mineral. 1999, 37, 929-938.

52. Mereiter, K. Crystal-structure and crystallographic properties of a schrockingerite from Joachimsthal. Tschermaks Mineral. Petrogr. Mitt. 1986, 35, 1-18. [CrossRef]

53. Mereiter, K. Synthetic swartzite, $\mathrm{CaMgUO}_{2}\left(\mathrm{CO}_{3}\right)_{3} \cdot 12 \mathrm{H}_{2} \mathrm{O}$, and its strontrium analog, $\mathrm{SrMgUO}_{2}\left(\mathrm{CO}_{3}\right)_{3}$. $12 \mathrm{H}_{2} \mathrm{O}-\mathrm{Crystallography} \mathrm{and} \mathrm{crystal-structures.} \mathrm{Neues} \mathrm{Jahrb.} \mathrm{Mineral.} \mathrm{1986,} \mathrm{1986,} \mathrm{481-492.}$

54. Vogl, J.F. Drei neue Mineral-Vorkommen von Joachimsthal. In Jahrbuch der Kaiserlich Königlichen Geologischen Reichsanstalt; K.K. Hof- und Staats-Druckerei: Vienna, Austria, 1853; Volume 4, pp. 220-223.

(C) 2018 by the authors. Licensee MDPI, Basel, Switzerland. This article is an open access article distributed under the terms and conditions of the Creative Commons Attribution (CC BY) license (http:/ / creativecommons.org/licenses/by/4.0/). 